\title{
Not All Experience is Created Equal: MP Career Typologies and Ministerial Appointments in the Canadian House of Commons, 1968-2015
}

\author{
Matthew Kerby ${ }^{1 \star(D)}$ and Feodor Snagovsky ${ }^{2}$ \\ ${ }^{1}$ School of Politics and International Relations, Australian National University, Canberra, Australia, and \\ ${ }^{2}$ School of Politics and International Relations, Australian National University, Canberra, Australia \\ ${ }^{*}$ Corresponding author. Email: matthew.kerby@anu.edu.au
}

(Received 5 June 2018; revised 3 September 2019; accepted 6 September 2019)

\begin{abstract}
While there is widespread agreement in the ministerial promotion and resignation literature that experience matters, experience has typically been defined as the length of time a legislator has worked in politics or served in a legislature. This approach fails to account for the different kinds of experience legislators accumulate as they progress through their political careers prior to appointment to cabinet. We demonstrate how researchers can use sequence and cluster analysis to obtain a more complete understanding of ministerial appointment. We identify four data-driven archetypes of political careers in Canada for the period 1968-2015. We find that MPs with diverse political careers are more likely to be appointed to cabinet, while MPs with opposition experience are more successful than MPs with government experience. We also find that parliamentary secretary is not necessarily a stepping stone to a full cabinet position, calling into question traditional conceptions of parliamentary politics as a 'ladder'.
\end{abstract}

Keywords: cabinet ministers; elites; political careers; ministerial appointment; sequence analysis

Few observers of Westminster democracies would say that Justin Trudeau, John Howard and David Cameron - three recent prime ministers from three different countries and three different positions on the ideological spectrum - share much in common. Each came to power at a different time under a different package of policy promises; nevertheless, each began his prime ministerial career in the same way, and each tells us something about how cabinets are formed and legislative careers take shape.

In 2015, Justin Trudeau made international headlines after appointing the first gender-parity cabinet in Canada's history. His ministry was notable for another reason: it was made mostly of rank political amateurs. More than half of Trudeau's cabinet - including those in senior portfolios such as finance, justice and defence - had been elected to the House of Commons for the first time in 
the 2015 election. Meanwhile, political veterans like Hedy Fry and John McKay, who had each been in parliament for almost 20 years, fell short of making the cut.

Likewise, when John Howard's coalition formed government in Australia in 1993 and David Cameron's Conservatives formed government in the UK in 2010, each of their parties had been out of power for almost 15 years. Even with a dearth of cabinet experience after such long periods in opposition, both prime ministers left some of their most loyal and long-serving MPs out of government.

What types of experience matter most for legislators in Westminster systems when it comes to ministerial appointment, and how can we better understand the pre-ministerial period of time these MPs spend in parliament?

A sizeable literature examines ministerial careers from both single-case and comparative perspectives (Berlinski et al. 2012; Dowding and Dumont 2009, 2014). This literature typically considers and measures 'experience' in a simple, monolithic way - usually the sum of the total time (days, months or years) since the political actor was first elected to parliament. While Westminster parliaments contain many examples like those from Canada, Australia and the United Kingdom, existing models of political experience cannot explain why some MPs' experiences count more than others' when prime ministers make their appointment decisions. We add to this literature by re-conceptualizing how political experience influences ministerial appointment. In so doing, we move models of cabinet appointment away from a static list of pre-cabinet positions to examining how various types of trajectories affect the likelihood of appointment.

In this article, we argue that experience has to do with what legislators do in parliament, rather than simply how long they do it. All career trajectories contain critical junctures, turning points and pathways. These events can shape the longevity and/or success or failure of the career itself. We use the Canadian case to highlight a particular reality many prime ministers face; while previous parliamentary experience matters for cabinet appointment, prime ministers are often forced to pick political amateurs. Moreover, they may sometimes find it preferable to do so, a notion which suggests not all careers of equal duration are, indeed, equal.

In order to account for this variation within a political career, we propose and introduce a new, more nuanced way to think about political experience. Our new experience variable is derived from a sequence analysis of pre-cabinet political experience. While in the context of this study we describe a series of data-derived archetypal Canadian careers, our measure is generalizable across a variety of political contexts.

After deriving this new variable, we employ a logistic regression to determine the likelihood of ministerial appointment according to career type while controlling for biographical and institutional variables. We find that the parliamentary careers the 'ministrables' (MPs eligible for ministerial appointment) hold at the time they are considered for cabinet appointment affects the likelihood of ministerial appointment. In line with our expectation, we find a positive relationship between diverse parliamentary experience reflected by a career that contains previous cabinet and/or extra-parliamentary experience, and appointment to cabinet. Surprisingly, ministrables with parliamentary careers that are best characterized as 'government party backbencher' had a lower likelihood of ministerial appointment than ministrables who spent most of their careers in the opposition ranks. We discuss some 
reasons why this might be the case. We also find evidence that the long-standing trope of working one's way up the political career 'ladder' may not be the best way to think about political careers. In fact, ranks such as parliamentary secretary the political equivalent of 'middle management' - may signal the death knell of political ambition.

In addition to a more accurate model of ministerial appointment, this study makes two further contributions to the study of political elites in Westminsterstyle parliamentary democracies. First, it introduces a novel, generalizable way to conceive of and measure legislators' political experience through the use of sequence analysis. By creating a measure of experience that moves beyond a duration count, we are able to establish a more finely tuned instrument for the continuing study of ministerial appointments in particular and elite careers more generally. Second, it brings together qualitative and quantitative understandings of what experience means and why it matters. In so doing, we propose a systematic way to incorporate certain unobservable characteristics that ministrables have which are relevant not only for their own political success, but ultimately the success of the governments they serve.

\section{Experience and ministerial appointment in Canada}

Cabinet ministers in Canada are appointed in the typical Westminster fashion - by the governor general, on the advice of the prime minister. Most recent ministries had between 30 and 40 cabinet ministers, including the prime minister. Since all of Canada's recent governments have been formed by a single party, prime ministers have almost unlimited power and discretion in deciding who sits at the cabinet table.

In the Canadian context, gender, professional background, geography, regional representation, education and experience are all significant predictors of cabinet appointment (Kerby 2009; Tremblay 2013). The impact of gender in particular has received considerable attention across a variety of contexts, including the different types of experience that men and women legislators bring to office (Escobar-Lemmon and Taylor-Robinson 2005, 2016; Krook and O'Brien 2012; Martin 1989). Women's representation in cabinet has improved significantly over time at both the provincial and federal levels of government. From 1976 to 1994, Canada's 10 provincial cabinets moved from having less than $4 \%$ to almost $21 \%$ of women ministers (Moncrief and Studlar 1996; Studlar and Moncrief 1997, 1999). The number of women first ministers has also increased: in 2013, at the most recent peak of women's representation in Canadian premierships, more than $85 \%$ of the population of Canada were under the leadership of women first ministers (Statistics Canada 2017). Women's substantive representation, however, continues to be unequal. Women ministers tend to 'head ministries dealing with social citizenship or social welfare activities', while men hold 'more portfolios related to the defining and physical resource mobilization activities of government' (Trimble and Tremblay 2005: 31).

A common argument in political science is that 'experience matters' for ministerial appointment - put simply, that experienced MPs are more likely to be appointed to cabinet (Atkinson and Docherty 1992; Heard 1991; Kerby 2009). 
However, beyond accounting for prior cabinet experience, these arguments have largely avoided discussions of the type of experience that matters most (Curtin 2014; Dowding and Lewis 2014; Kenig and Barnea 2014; Kerby 2014; Mufti 2014; Nikolenyi 2014). The importance of previous parliamentary experience and its relationship to ministerial appointment can be traced back to delegation theory. Prime ministers try to avoid agency loss when they appoint their ministers to cabinet, whether through adverse selection costs (incompetence) or moral hazard (a deviation in agenda between the minister and the prime minister). Prime ministers do this through ex ante mechanisms such as interviews, background checks, recommendations via networks, and so on. While a dramatic change in personnel or an injection of new blood into cabinet can foster new ideas and a fresh perspective on a government's policy agenda, it comes with the risk of error, scandal or failure. Inexperienced ministers may lack the capacity, know-how and wherewithal to handle the administrative and political complexities of managing a government portfolio.

This said, we believe the 'days spent in parliament' metric of experience is inadequate as it fails to account for the diversity of experience MPs can hold. For instance, is time on the government backbenches more valuable than time on the opposition backbenches? Does being an opposition critic make a legislator more likely to be appointed than being a parliamentary secretary? Finally, does the order in which MPs hold these positions matter?

This notion suggests legislators can be grouped into 'types' - and that some types of experience are more likely to lead to ministerial appointment than others. However, despite long-standing interest in typologies of legislators and executives (e.g. Searing 1985, 1987, 1994), the fruits of such labour have not extended to explaining ministerial appointment. The most prominent typologies of parliamentary careers account for the various goals and ideals held by backbench legislators. Donald Searing $(1985,1987,1994)$ uses cross-sectional survey data to distinguish between four broad categories of backbenchers: Policy Advocates, Ministerial Aspirants, Constituency Members and Parliament Men. Each role is the result of rational actors adapting their goals to the incentive structures available to them; 'Ministerial Aspirants, for instance, are strong on ambition and often manage to reshape their backbench roles with strategies that "make a mark," that "strengthen their positions" and help ensure that when the time comes to be judged, their goals will be fulfilled' (Searing 1994: 22). The combination of goals and incentives affects where MPs choose to spend most of their time and the votes they cast in parliament, as well as the committees and agendas they pursue. However, few are totally immune to the allure of a ministerial career: 'the vast majority of career politicians are ambitious in the generally-understood sense ... They are eager for office and promotion and, if they are offered them, will accept with alacrity' (King 1981: 282). Indeed, inside knowledge or self-awareness may lead a rational legislator to update their goals in light of the incentives available to them - for instance, by turning to constituency service or other forms of parliamentary work.

While useful in understanding the backbench experience, separating parliamentarians into categories can also help prime ministers decide which MPs to appoint to the ministry. Selecting cabinets presents a principal-agent problem for prime ministers as they decide which legislators would best use their authority to further 
the prime minister's agenda (Berlinski et al. 2009, 2010). The literature on ministerial careers typically relies on ministerial duration - how long a minister spends in cabinet - as a proxy for success. Duration signals resolution of the prime minister's delegation problem: having weighed the pros and cons of keeping a minister in cabinet, a net cost would lead to that minister being replaced. Put simply, successful ministers are those who 'last' (Kerby 2011).

What, then, is a prime minister to do when selecting a cabinet? While prime ministers are unlikely to calculate predicted survival rates for each potential minister, they are much more likely to have compared each potential 'agent' to some set of desirable criteria. Further, in the absence of other evidence, 'prime ministers will theoretically examine each potential minister in their parliamentary party and compare them to an ideal average minister' (Kerby 2011: 600). We expect the 'types' of legislator that attract a prime minister's gaze to be those who have demonstrated executive experience - in the first instance, legislators who have served in prior ministries. Failing that, we expect prime ministers to prefer legislators with a diversity of parliamentary experience - not simply a long history of it. In fact, a prime minister may be hesitant to select those MPs with a long history of parliamentary service but limited upward mobility. Such MPs may have failed to rise above the backbenches for good reason - perhaps either because of their lack of interest in higher office or perceived lack of competence. We also expect experience as a shadow minister (or 'critic', as they are known in Canada) to matter. The reasoning for this is straightforward: critics resolve the same delegation problem for opposition leaders that ministers resolve for prime ministers. Experience of closely tracking a portfolio and articulating the leader's message represents a good proxy for how the individual might act in the ministry. Further, we expect opposition experience to matter more than government backbench experience because the Canadian context is marked by long, alternating, stretches of single-party rule with either the Liberals or Conservatives in power. Barring catastrophe, government backbenchers who were passed over at the beginning of a ministry will never experience a situation where more cabinet positions are left to be filled. By contrast, legislators cannot be appointed to cabinet when in opposition - thus, their moment could still be yet to come.

\section{Legislative careers in Canada}

The puzzle of ministerial appointment and experience is interesting in the Canadian context, where politics are characterized by high levels of parliamentary amateurism for both MPs and cabinet ministers (Matland and Studlar 2004). This results in what some have referred to as an amateur elected chamber (Atkinson and Docherty 1992; Docherty 2011; Franks 1987). Amateurism poses a problem in a Westminster system for those who worry about the relative power of the executive compared to the legislature, especially in Canada where prime ministers and their cabinet ministers are much more likely to enjoy longer terms in the House of Commons than their backbench colleagues (Docherty 1997). This concern comes in the context of a wider debate on the role and influence of the executive relative to private members (Savoie1999). Matthew Kerby and Kelly Blidook (2011) find MPs' expectations when they first start their job affect their individual calculations 
of whether to seek re-election or leave political office. The Canadian House of Commons offers its members little influence, autonomy and few opportunities for advancement, and MPs who enter parliament with the primary motivation of making a difference appear to be least satisfied of all. Indeed, these members are more than twice as likely to exit parliament voluntarily as compared to their colleagues who see their role primarily as a representative of their party. MPs whose first motivation is constituency service appear to be no more likely to leave voluntarily than the parliamentary average. Thus, cabinet positions are prized by backbench MPs for a range of political goals: either increasing prestige and authority (office) or instrumental benefits (policy or votes) (Docherty 1997; Kerby 2011; Müller and Strøm 1999; Snagovsky and Kerby 2018).

The high levels of turnover in the Canadian House of Commons make it an interesting and important case for examining ministerial appointment because it represents a bleak delegation problem for Canadian prime ministers - they are forced to make decisions with limited information while facing constraints such as a limited pool of candidates, high levels of legislative turnover which render many potential ministers inexperienced and accident prone, party considerations, and political principles' (Kerby 2009: 594). As such, the decisions of Canadian prime ministers are instructive to executives in other countries who find themselves making similar decisions with other types of constraints (and, as we describe above, such situations are relatively common). From a methodological point of view, Canada is also interesting because of the greater variation in career type that arises from higher levels of legislative turnover. This allows us to ask: if prime ministers 'run out' of experienced hands in the form of prior ministers, who do they turn to?

\section{Data and methods}

We employ a three-pronged approach to investigating how political experience impacts ministerial appointment. The first element consists of a sequence analysis of the complete pool of ministrables (MPs eligible for ministerial appointment) for the period 1968-2015. ${ }^{1}$ Second, we use cluster analysis to identify similarities between different sets of ministrable career trajectories. Finally, we estimate a logistic regression using the resulting career archetypes to explain the relationship between experience and ministerial appointment. We elaborate on each of these three steps below.

Of the methods mentioned above, the use of sequence analysis may be least familiar to most political scientists. While sequence analysis was first developed to help geneticists decode strings of deoxyribonucleic acid (DNA), its use in the social sciences is not completely novel; for example, sociologists have used sequence analysis to model individual life trajectories and retirement patterns (Aisenbrey and Fasang 2010; Fasang 2012). In the context of political elites, sequence analysis has recently been used to model political career trajectories in Germany, Spain and the Netherlands (Jäckle 2014; Manow 2012; Real-Dato and Alarcón-González 2012; Tepe and Marcinkiewicz 2013; Zwinkels and Mills 2015), judicial careers in Germany and Canada (Jäckle 2016; Kerby and Banfield 2013) and ministerial staff careers in Australia (Taflaga and Kerby 2019). ${ }^{2}$ 
Sequence analysis begins by mapping the duration a person remains in a specified state, and then calculates the distances between each state. The result of the sequence analysis is typically interpreted through a state distribution plot which records how long each unit (in this case, an MP) spends in a given state. This process is different to event history analysis (EHA), a related method which readers of this journal may be more familiar with. EHA models the hazard, or probability, of an event occurring. In the context of ministerial careers, this could mean the probability of ministerial appointment conditional on where an individual is situated in their political career. However, EHA can only explain career transitions; by contrast, sequence analysis creates a more holistic model of the complete career trajectory (Jäckle and Kerby 2018). This advantage is critical, since 'single transitions which mark specific developments or setbacks in the course of a political career can and should not be uncoupled from earlier events' (Jäckle and Kerby 2018: 123).

We sequence the population of Canadian ministrables for the period 1968-2015 $(\mathrm{N}=2109)$. These dates correspond with the contemporary period of Canadian federal politics; it is a period that spans from the beginning of Pierre Elliot Trudeau's first ministry and lasts until the formation of Justin Trudeau's first cabinet, which was sworn in to office shortly after the 2015 federal general election. Each observation in the data set consists of a single ministrable and records their complete parliamentary career path from the point that they were first elected to parliament until an appointment opportunity: either the beginning of a ministry or the month immediately following a general election. ${ }^{3}$ The unit of observation is the ministrable at each appointment opportunity. Given that ministrables may serve in multiple ministries (e.g. Jean Chretien served in Pierre Trudeau's first (1968) and second (1980) ministries as well as John Turner's short-lived 1984 ministry), single individuals may have multiple records in the data set. In this respect, each instance an MP was eligible for appointment to cabinet is recorded as a separate observation, since from the prime minister's perspective the ministrable looks qualitatively different after the passage of time and the accumulation of experience. We also account for those periods of time that ministrables spent outside of parliament prior to returning to elected office. For example, Liberal Brian Tobin served as an MP for the period 1980-96, at which point he resigned from the House of Commons (and the cabinet) in order to run for the premiership of the province of Newfoundland and Labrador. He was premier from 1997 until 2000, when he was re-elected to the House of Commons where he served as a cabinet minister until he resigned in 2002. The data set accounts for Tobin's extra-parliamentary stint and codes that period as 'out of parliament'.

We break down parliamentary careers into 11 categories/career states: out of parliament (the MPs has resigned from parliament or lost their seat in an election and is working in the private or public sector, but eventually returns), third party opposition MP (i.e. not the official opposition), official opposition party backbencher, official opposition party critic, official opposition party leader, governing party MP (backbencher), parliamentary secretary (not of cabinet), minister of state, cabinet minister, elite minister (e.g. minister of finance, minister of foreign affairs, president of the Treasury Board) and prime minister. In the language of sequence analysis, these 11 categories form the 'alphabet' of our analysis. While we recognize that MPs can hold numerous responsibilities in addition to their other roles 
(e.g. committee chair, party whip etc.), we opt for simplicity with a list of clearly defined, hierarchical and salient roles that ministrables can hold.

Next, to find patterns in our sequence plots and to group parliamentary careers into archetypes, we perform a cluster analysis. Cluster analysis is used to group individuals with similar trajectories, using a range of techniques to identify the optimal number of clusters. In order to do this, we first draw on the data contained in career sequences and calculate the proximities (or distances) between the different career states. There are multiple approaches to accomplish this task. The most common procedure is the so-called optimal matching (OM) analysis approach. The basic idea is to transform a sequence $\mathrm{A}$ into another sequence $\mathrm{B}$ using different types of transformation operations (substitutions, insertions and deletions). For each of these operations, a certain cost is set (either unitary - the same for all transformations, theory based, or derived from the empirical transition data). The OM algorithm then finds the specific transformation procedure that has the lowest costs. The number of operations necessary for this lowest cost transformation is defined as the distance between sequences $\mathrm{A}$ and $\mathrm{B}$ (Lesnard 2014: 40; Robette and Bry 2012). A variant of the OM procedure, which is well suited for biographical research as it measures the resemblance of career trajectories in a way that comes close to social scientists' understanding of the term 'similarity of trajectories' is the longest common subsequence (LCS) proposed by Cees Elzinga (2006: 14-16), also known as the Levenstein II distance. Our analysis of Canadian ministerial appointments follows suit and employs the LCS approach. After we have calculated the LCS distances, we use a cluster analysis on the sequences using the Ward method, the most commonly used algorithm for determining clusters. This data-driven process groups the observations in our model according to which of the sequences have the lowest LCS distance from each other - that is, which are most similar. The results of a dendrogram, scree and silhouette plot (see online appendix) suggest the optimal number of clusters that fit our data is four.

Conceptually, the result of employing sequence analysis to visualize career states and then using cluster analysis to group these career states into distinct 'types' replicates the perspective of a prime minister as she decides who to appoint at the beginning of a ministry. In this case, our data-driven approach suggests that if a prime minister examines the population of potential cabinet ministers according to our framework, she would see four broad types of pre-ministerial careers. We elaborate on these four types of career trajectories below.

After identifying the pre-appointment career archetypes for each ministrable, we employ a logistic regression to estimate the effect of the parliamentary experience archetype factor variable on the likelihood of ministerial appointment. In addition to the primary independent variable of interest, we also include a selection of both personal and political control variables to account for alternative factors that may contribute to the likelihood of ministerial appointment. We control for the age of the ministrable, their gender, whether they come from a legal background, previous background in provincial-level politics, political party, minority government status, and finally the size of the ministrable pool, as each has been shown to influence the likelihood of ministerial appointment in Canada (Kerby 2009, 2011). 


\section{Results}

\section{Sequence analysis}

We visualized the career paths of all Canadian ministrables using sequence index plots, which graphically represent the time, order and role that each ministrable holds. Figure 1 depicts the career sequences for the first 10 ministrables in the data set. We also present all the career sequences in a state distribution plot (Figure 2) which records the proportion of career roles/states occupied by ministrables for each month in which they are being observed.

At first glance, we can see that the proportion of roles occupied by ministrables changes over time. The modal category at the start of a career is governing party MP; only a small proportion of MPs occupy a seat in cabinet as a full cabinet minister. As ministrables advance through time we can see that a higher proportion occupy positions as parliamentary secretaries and indeed an increasing number take on roles as cabinet ministers. A convenient feature of the state distribution plot is the ability to subset by factor, such that we can look at the career paths of ministrables who are eventually appointed to cabinet and compare them with those who are passed over. For example, Figure 3 shows us that while the careers of these two classes of ministrables look somewhat similar, there are nevertheless a number of distinctions: for example, ministrables who are not appointed to cabinet appear to have served as a parliamentary secretary at a later stage in their careers while the proportion of ministrables who go on to become ministers serve as parliamentary secretary earlier in their careers and in smaller proportion. We return to this puzzle below. Second, and not surprisingly, cabinet experience appears to beget further cabinet experience.

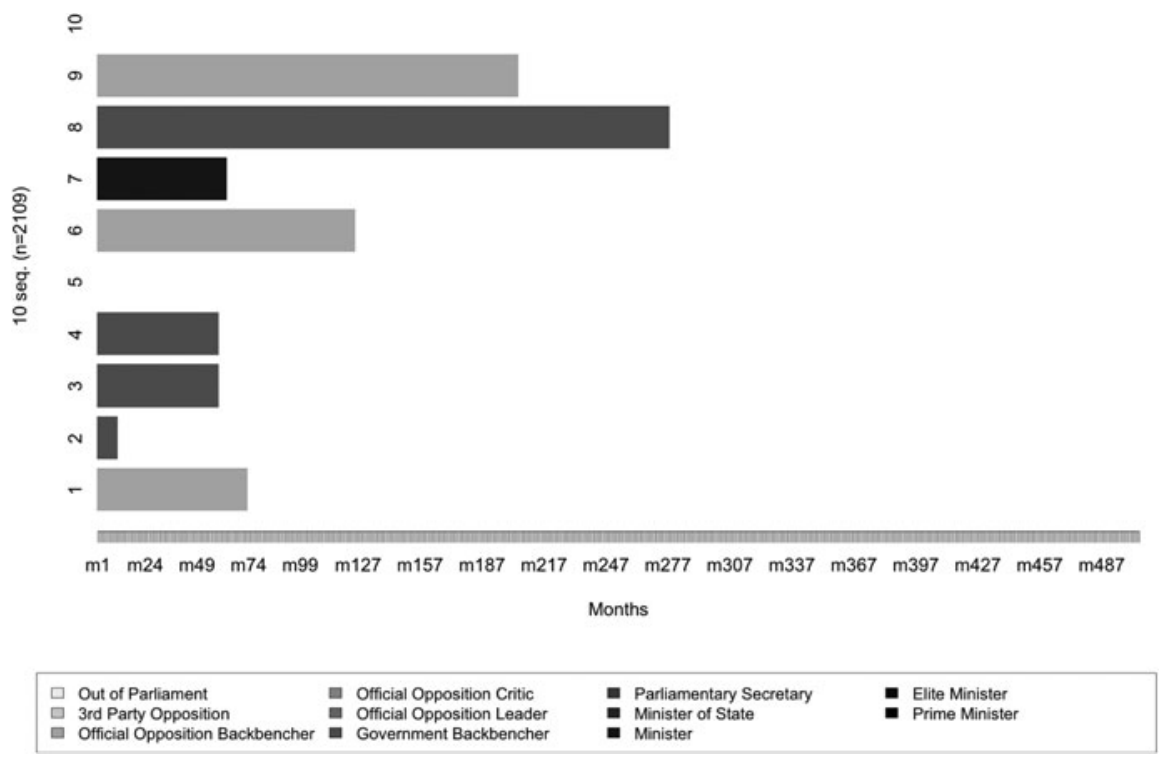

Figure 1. Sequence Index Plot of Canadian Ministrable Careers (1968-2015) 
10 Matthew Kerby and Feodor Snagovsky

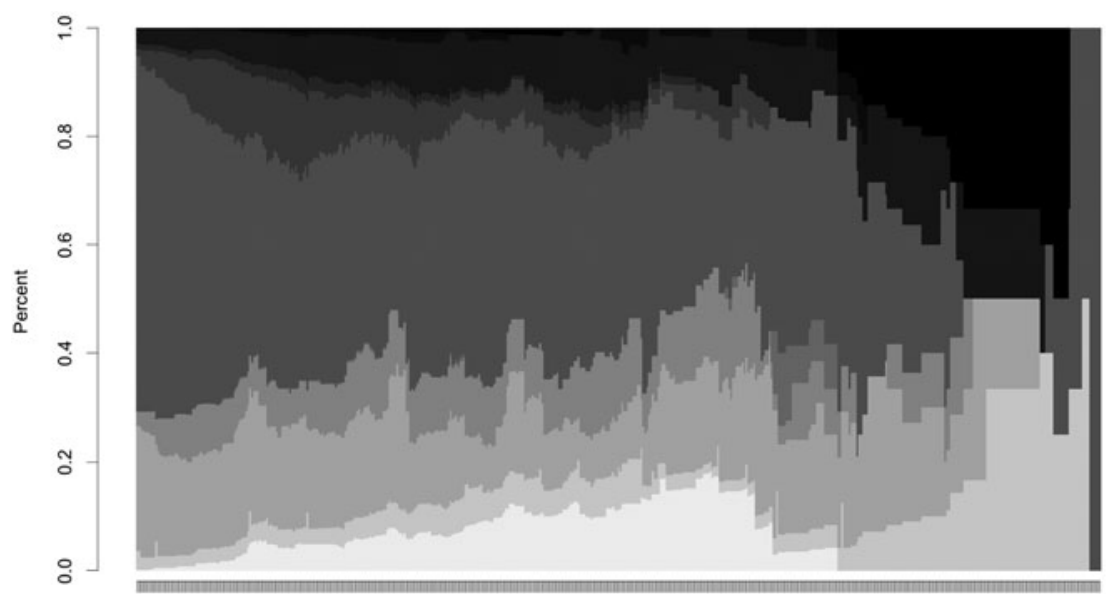

m1 m26 m53 m80 m110 m143 m176 m209 m242 m275 m308 m341 m374 m407 m440 m473

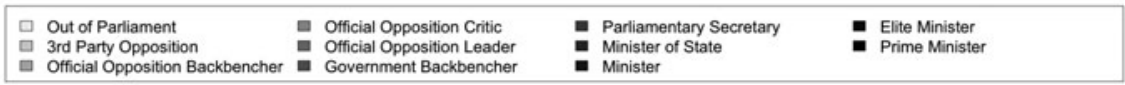

Figure 2. State Distribution Plot of Canadian Ministrable Careers (1968-2015)
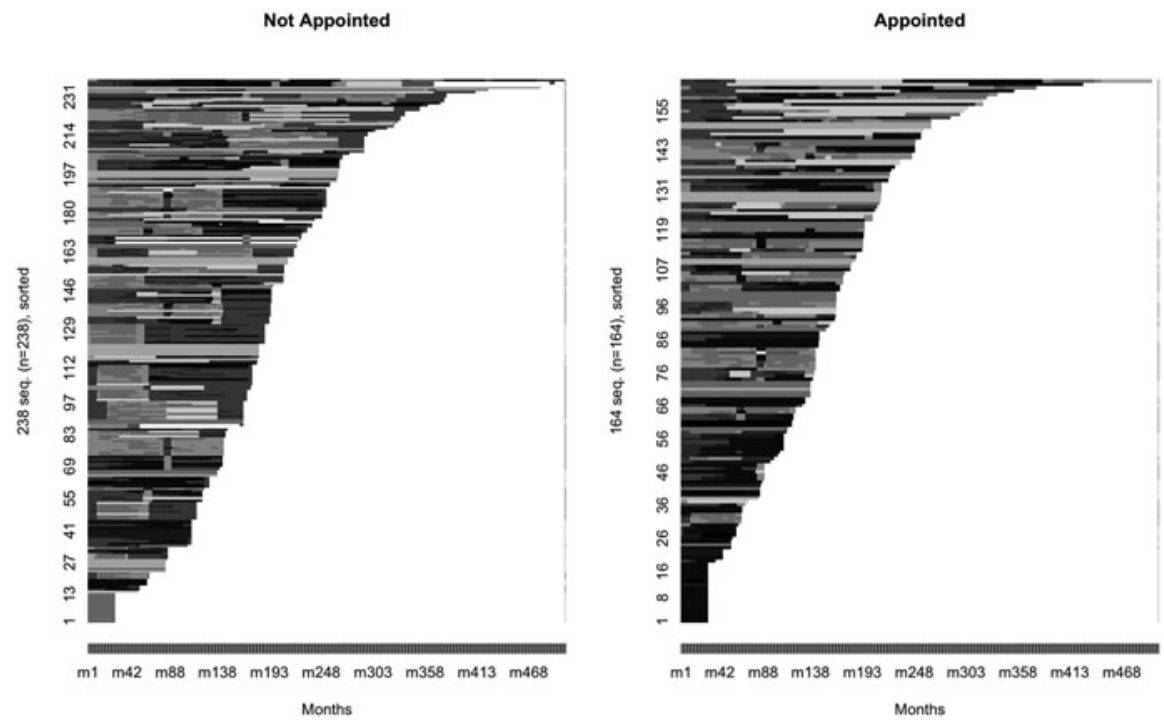

\begin{tabular}{|c|c|c|c|c|}
\hline 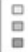 & $\begin{array}{l}\text { Out of Parliament } \\
\text { 3rd Party Opposition } \\
\text { Official Opposition Backbencher }\end{array}$ & $\begin{array}{l}\text { - Official Opposition Critic } \\
\text { - Official Opposition Leader } \\
\text { - Govemment Backbencher }\end{array}$ & $\begin{array}{l}\text { - Parliamentary Secretary } \\
\text { - Minister of State } \\
\text { - Minister }\end{array}$ & $\begin{array}{l}\text { - Elite Minister } \\
\text { - Prime Minister }\end{array}$ \\
\hline
\end{tabular}

Figure 3. State Distribution Plot of Canadian Ministrable Careers by Appointed to Cabinet Yes/No 
The results of our cluster analysis reveal four distinct clustered sequences; we plot them as state distribution plots in Figure 4. Those ministrables in the first category are labelled 'Neophytes'. This category consists of MPs who have little or no parliamentary experience and are eligible for appointment to cabinet after having been elected to the House of Commons for the first time. These MPs make up $27 \%$ of the ministrable pool.

The second category contains MPs who are best described as 'Opposition Holdouts'. These are the MPs who are elected to parliament as members of an opposition party and are appointed to cabinet when their party forms government. They typically have very little previous cabinet experience due to the long stretches of single-party government. These MPs account for $21 \%$ of the ministrable pool.

We refer to the third career category as 'Government Backbenchers'. MPs who follow this career trajectory typically begin their parliamentary careers as government party backbenchers and may then be appointed as a parliamentary secretary prior to appointment to cabinet. We note the plurality of MPs still serve on the government backbench prior to being considered for the cabinet. This is the modal category and contains $35 \%$ of our sample.

We label the fourth 'Diverse and Experienced'. This category consists of a much more heterogeneous group of ministrables, at least with respect to their careers. Here we find ministerial candidates from across all of the different parliamentarian positions included in our sequence alphabet. In addition to the variety, we also find across the time series noticeable proportions of ministrables who fall into the categories of minister and official opposition critic, as well as out of parliament. It appears that this category consists of those ministrables who have some kind of parliamentary or extra-parliamentary experience that extends beyond the backbenches; $21 \%$ of ministrables fall into this category. When we plot a sequence index graph for those 'Diverse and Experienced' ministrables by appointed/not appointed to cabinet (Figure 5) we see that the 124 MPs appointed to cabinet typically have more previous ministerial experience than those who are not.

Interestingly, those with the least parliamentary experience are those ministrables who reach the higher ranks in cabinet (e.g. elite ministers), whereas the longer durations contain a higher proportion of ministrables who spent time out of parliament prior to returning and being appointed to cabinet. For those 'diverse and experienced' ministrables who are not appointed to cabinet we observe one particularly unsettling trend for ambitious MPs looking to move up the political ladder. A sizeable proportion of these ministrables see their ambition curtailed once they reach the rank of parliamentary secretary. When compared to those ministrables who are appointed to cabinet, it looks as if an appointment to a parliamentary secretary position at a later stage in one's political career is in fact a political dead end.

\section{Logistic regression}

The results of our logistic regression are presented in Table $1 .{ }^{4}$ Our expectation that appointment to cabinet is positively related to the accumulation of experience is partially realized. When compared with those ministrables who fall into the 'Government Backbencher' reference category, we find that those ministrables 


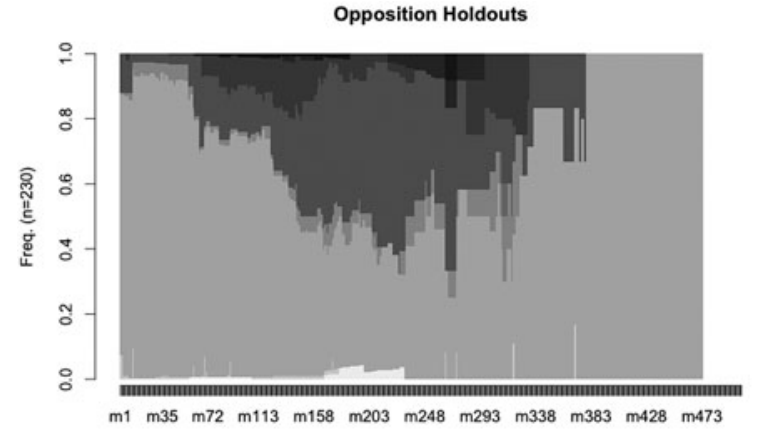

Neophytes

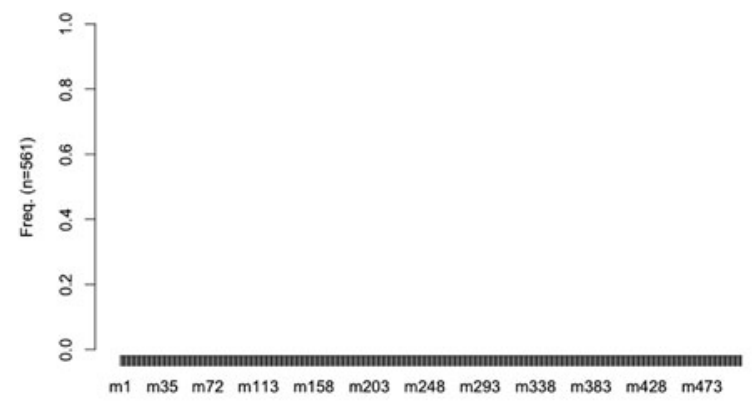

Government Backbenchers

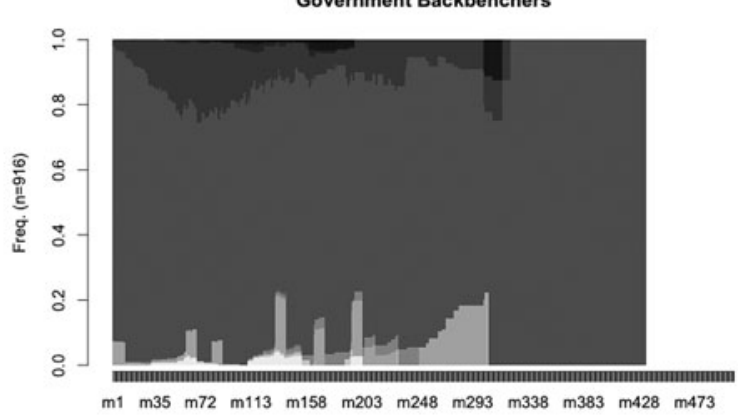

Diverse Experience

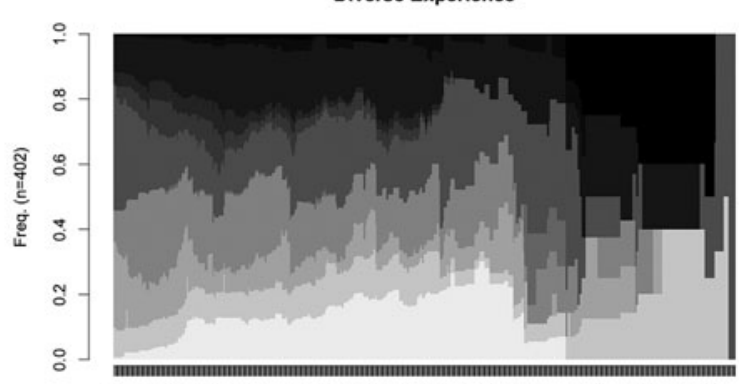

m1 m35 m72 m113 m158 m203 m248 m293 m338 m383 m428 m473
- Parliamentary Secretar

Minister of Stat

Minister
- Elite Minister

- Prime Minister

Figure 4. State Distribution Plot of Ministrable Careers by Clustered Career Type 


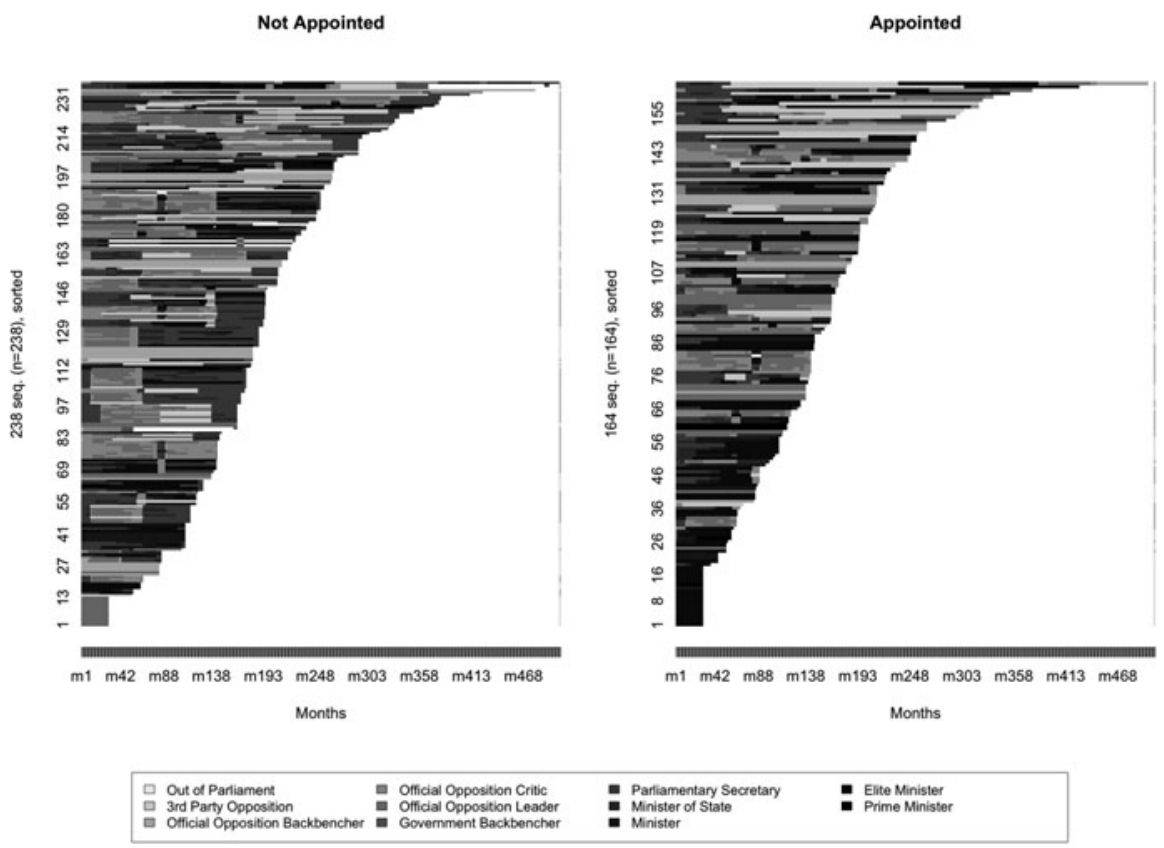

Figure 5. Sequence Index Plot: Cluster 04: Diverse and Experienced, by Appointment

who have careers that contain previous cabinet experience (or extra-parliamentary breaks) have odds of ministerial appointment that are 7.34 times that of the odds for government backbenchers. What is surprising is that the neophytes - those ministrables who have only just been elected to the House of Commons - have higher odds of appointment (odds ratio $=1.63$ ) than those ministrables who are coded as Government Backbencher. Indeed, the neophytes' odds ratio is about the same as that which was estimated for the ministrables whose careers were spent largely in the opposition ranks prior to consideration for cabinet (odds ratio $=1.73$ ). Each of the career cluster categories were statistically significant at the 0.05 level.

This unexpected result is likely related to the nature of the selection pool. Canadian cabinets are characterized by very small turnover. A cabinet on the first day of a parliament looks very similar to a cabinet on the last day of a parliament with respect to who is sitting around the table. When movement occurs, it is often horizontal within the cabinet; change in cabinet personnel is usually small and cosmetic. Given the long stretches of single-party government that exist in Canada, backbench MPs have to fight to get a seat in cabinet if they do not get one when it is first assembled. This process is further complicated by Canadian prime ministers' (understandable) habit of appointing ministers who have previous experience in order to avoid adverse selection and moral hazard problems.

The main opportunity to break this cycle takes place when there is a change in party government, and given the long durations of party government in Canada and high levels of legislative turnover this means the new pool of ministrables who are eligible for cabinet appointment are not likely to have much cabinet 
14 Matthew Kerby and Feodor Snagovsky

Table 1. Logistic Regression of Canadian Ministerial Appointment (1968-2015)

\begin{tabular}{|c|c|}
\hline & Probability of ministerial appointment \\
\hline \multicolumn{2}{|l|}{ Career type } \\
\hline \multicolumn{2}{|c|}{ Government Backbencher (reference category) } \\
\hline \multirow[t]{2}{*}{ Opposition Holdout } & $1.732^{\star}$ \\
\hline & $(0.388)$ \\
\hline \multirow[t]{2}{*}{ Neophyte } & $1.631^{\star \star}$ \\
\hline & $(0.259)$ \\
\hline \multirow[t]{2}{*}{ Diverse and Experienced } & $7.339^{\star \star \star}$ \\
\hline & $(1.216)$ \\
\hline \multirow[t]{2}{*}{ Age } & 1.055 \\
\hline & $(0.051)$ \\
\hline \multirow[t]{2}{*}{ Age2 } & $0.999^{\star \star}$ \\
\hline & $(0.001)$ \\
\hline \multirow[t]{2}{*}{ Female $=1$} & $2.004^{\star \star \star}$ \\
\hline & $(0.330)$ \\
\hline \multirow[t]{2}{*}{ Lawyer = 1} & $1.891^{\star \star \star}$ \\
\hline & $(0.252)$ \\
\hline \multicolumn{2}{|l|}{ Provincial experience } \\
\hline None (reference category) & - \\
\hline \multirow[t]{2}{*}{ Prov. MLA } & $1.862^{*}$ \\
\hline & $(0.514)$ \\
\hline \multirow[t]{2}{*}{ Prov. minister } & $2.048^{\star}$ \\
\hline & $(0.595)$ \\
\hline \multicolumn{2}{|l|}{ Party } \\
\hline \multicolumn{2}{|l|}{ LPC (reference category) } \\
\hline \multirow[t]{2}{*}{ PC } & $0.742^{\star}$ \\
\hline & $(0.104)$ \\
\hline \multirow[t]{2}{*}{$\mathrm{CPC}$} & 1.046 \\
\hline & $(0.215)$ \\
\hline \multirow[t]{2}{*}{ Minority government = 1} & 0.861 \\
\hline & $(0.120)$ \\
\hline \multirow[t]{2}{*}{ Ministrables } & $0.998^{\star}$ \\
\hline & $(0.001)$ \\
\hline $\mathrm{N}$ & 2109 \\
\hline Pseudo $\mathrm{R}^{2}$ & 0.1230 \\
\hline
\end{tabular}

Note: Exponentiated coefficients. Standard errors adjusted for 10 ministry clusters.

${ }^{\star} \mathrm{p}<0.05,{ }^{\star \star} \mathrm{p}<0.01,{ }^{\star \star \star} \mathrm{p}<0.001$. 
experience although they may have considerable opposition party experience. When prime ministers are faced with a choice between ministers who have opposition party experience and freshly elected MPs with no previous parliamentary experience at all, we expect them to choose those ministers with opposition party experience first. Indeed, our results bear this out, although the confidence intervals across these two groups overlap. Further, the most recent experience bucks expectation in that Justin Trudeau appointed 18 neophyte parliamentarians to his first 30-person cabinet in 2015.

Our results may also be skewed by the particular subset of data that we employ. Our logistic regression only considers ministerial appointments that take place immediately after a general election or following a change in prime minister. While cabinet turnover between elections for incumbent governments is small in scale, it still exists and the pool of ministrables to fill empty cabinet seats would likely be drawn from the 'Government Backbencher' category. However, as we discuss in the previous paragraphs, the relative incidence of these vacancies is small. Otherwise, when governing party turnover takes place, the majority of appointments will be drawn from the 'Opposition Party' category given the paucity of ministrables who have previous cabinet experience.

\section{Discussion and conclusion}

In theory, prime ministers devote considerable time and energy to building a cabinet that can deliver the party's policy agenda and survive (or ideally win) the next election. They weigh pros and cons, balance personalities and factions and ensure that representational needs are met, all while considering party priorities and matching individuals' skills and talents to tasks. As a result, ministerial duration has come to be regarded as a metric of success: from a prime minister's perspective, successful cabinet ministers are those who do not need to be replaced.

How is a prime minister to anticipate which legislators would be most successful in cabinet? Most models of ministerial appointment agree that 'experience matters'. To this point, researchers have measured experience in terms of days, months or years spent in parliament. However, these models ignore the fact that many legislators spend their entire careers on the backbenches, and yet are no closer to sitting around the cabinet table.

With this analysis, we have argued that what legislators do in parliament matters more than how long they do it for. As a result, we argue, studies of legislative and ministerial careers must consider how the dimensions of parliamentary experience factor into models of legislator and ministerial behaviour. To this end, we conceptualize a new model of legislator experience and use sequence analysis to model parliamentary careers. Conceptually, this data-driven method of examining preappointment careers replicates the dilemma prime ministers face when deciding who to promote to cabinet. A prime minister who agrees that parliamentary experience is a relevant predictor of ministerial success may have several different ways to see that experience. We present one such approach - grouping MPs according to the roles they have played in parliament. Accordingly, a prime minister following our framework would see four broad types of pre-ministerial careers as she looks to appoint her front bench. 
We call the first type of pre-ministerial parliamentary career a prime minister would see the 'Neophyte' - an MP with little-to-no parliamentary experience who has just made their way to the House of Commons for the first time. These legislators make up just over one-quarter of the ministerial selection pool and can only rely on their pre-parliamentary experience to advocate for a seat at the cabinet table. We refer to a second category, 'Opposition Holdouts' - MPs who have paid their dues as members of the opposition, whether as critics or shadow ministers, or simply as private members. We label the third category 'Government Backbenchers': legislators who have spent some time as private members in the government or perhaps some time as parliamentary secretaries. We call the final category 'Diverse and Experienced' - a much more heterogeneous set of seasoned hands with a range of experience to draw upon.

As our results make clear, the data-driven, empirical approach we use to categorize these types of careers results in cross-cutting and distinct typologies to those advanced in previous research. For example, each type of career described above represents a conceptual mix of several of Searing's (1994) original typologies. We expect that our category of 'Government Backbenchers' contains each of Searing's four types: Policy Advocates, Ministerial Aspirants, Constituency Members and Parliament Men. However, despite their aspirations, our results suggest their outlooks are all similar, at least from the perspective of appointment: bleak.

When we examine our types using a logistic regression to model ministerial appointment in Canada between 1968 and 2015, we find there is a hierarchy of political career types that lead to ministerial positions. Some legislators languish on the backbenches almost indefinitely, and the time they serve in parliament is unlikely to help their ministerial prospects. Traditional measures of experience such as 'number of years in parliament' do not capture this experience. Our results also raise new questions; we demonstrate that a residency in the opposition ranks may facilitate upward mobility into cabinet better than winning a backbench seat on the government side. This then raises questions as to the applicability of traditional ambition models of political career progression with respect to the Canadian case. These results also subtly undermine the prevailing wisdom of a career 'ladder' in politics, where MPs work their way up from the backbenches to senior cabinet portfolios. For example, our data show the rank of parliamentary secretary is often a political dead end for the ambitious legislator.

In addition to a more accurate understanding of ministerial appointment, this study introduces a novel, generalizable way to think about and measure legislators' political experience through the use of sequence analysis. We do not claim to invent a new theoretical typology of political elites that is consistent across all parliamentary contexts. Rather, our approach invites researchers to apply these ideas and methods to their own contexts so that we can begin to truly compare how career trajectories differ between cases.

Further, this study reconciles quantitative and qualitative conceptions of what 'experience' means and how we can identify it. The former argues that experience is something we must be able to measure precisely - to this point, it has been defined as a simple measure of time. The latter argues this way of thinking is too simplistic, and parliamentary experience must be thought of in a holistic way. 
However, this prevents rigorous and systematic comparison between different countries and ministries. Our approach addresses traditional quantitative shortcomings by capturing the unobserved heterogeneity in the various dimensions of parliamentary experience while creating a measure that allows easy comparison between cases. Since our new framework is generalizable across a variety of legislative contexts, we hope it will facilitate comparative research in the study of political careers by considering how political experience matters beyond simple duration.

Supplementary material. To view the supplementary material for this article, please visit https:/doi.org/ 10.1017/gov.2019.29.

Acknowledgements. We would like to thank the editors and reviewers for their helpful comments and suggestions. We also received valuable feedback on earlier iterations of this research at the 2017 European Political Science Association Annual Conference and the 2017 Midwest Political Science Association Annual Conference.

\section{Notes}

1 It is impossible to include non-parliamentary candidates in our selection pool. Fortunately, the appointment of individuals to cabinet who do not hold a seat in the House of Commons is a rare occurrence. Indeed, since the start of our time series (1968), only seven ministers were appointed to cabinet from outside parliament. Outside appointments are typically eschewed in the Canadian context, not only because of the risk that the minister may fail to win a seat in the House of Commons (e.g. Pierre Juneau and Charles Granger) and thus embarrass the prime minister, it also creates dissent among backbenchers who patiently wait for their opportunity to enter the cabinet.

2 For a further review of sequence analysis and its applicability to the social sciences, see Blanchard et al. (2014) and Jäckle and Kerby (2018).

3 We leave the question of mid-parliament cabinet reshuffles for future research, as these are usually small scale and greatly increase the complexity of the model.

4 We ran additional specifications with fixed effects for both aboriginal status and for ministrables' province. The inclusion of these variables had no effect on the remaining coefficients. These additional specifications are included in the online appendix. We also did not include a French-/English-speaking variable. Not only is this variable difficult to quantify, but we also do not think language spoken or bilingualism is a condition for ministerial appointment. True, since Brian Mulroney's prime ministership it is essential that the prime minister is able to speak both official languages fluently, but a less stringent standard is applied to cabinet ministers. Indeed, there are well-known cases of ministers whose grasp of a second official language was/is limited at best. We note that Graham Fraser, the Canadian Commissioner of Official Languages, publicly stated in 2016 that bilingualism is not a requirement for cabinet ministers, nor should it be.

\section{References}

Aisenbrey S and Fasang AE (2010) New Life for Old Ideas: The 'Second Wave' of Sequence Analysis Bringing the 'Course' Back into the Life Course. Sociological Methods and Research 38(3), 420-462.

Atkinson MM and Docherty D (1992) Moving Right Along: The Roots of Amateurism in the Canadian House of Commons. Canadian Journal of Political Science 25, 295-318.

Berlinski S, Dewan T, Dowding K et al. (2009) Choosing, Moving and Resigning at Westminster, UK. In Dowding $\mathrm{K}$ and Dumont P (eds), The Selection of Ministers in Europe: Hiring and Firing. London: Routledge, pp. 58-78.

Berlinski S, Dewan T and Dowding K (2010) The Impact of Individual and Collective Performance on Ministerial Tenure. Journal of Politics 72(2), 559-571.

Berlinski S, Dewan T and Dowding K (2012) Accounting for Ministers: Scandal and Survival in British Government 1945-2007. Cambridge: Cambridge University Press.

Blanchard P, Bühlmann F and Gauthier J-A (2014) Advances in Sequence Analysis: Theory, Method, Applications, Vol. 2. Heidelberg: Springer. 
Curtin J (2014) New Zealand: Stability, Change or Transition? Achieving and Retaining Ministerial Office. In Dowding K and Dumont P (eds), The Selection of Ministers Around the World. Abingdon: Routledge, pp. $25-43$.

Docherty D (1997) Mr. Smith Goes to Ottawa: Life in the House of Commons. Vancouver: University of British Columbia Press.

Docherty D (2011) The Canadian Political Career Structure: From Stability to Free Agency. Regional and Federal Studies 21(2), 185-203.

Dowding K and Dumont P (2009) Structural and Strategic Factors Affecting the Hiring and Firing of Ministers. In Dowding $\mathrm{K}$ and Dumont $\mathrm{P}$ (eds), The Selection of Ministers in Europe. London: Routledge, pp. 1-20.

Dowding K and Dumont P (eds) (2014) The Selection of Ministers Around the World. Abingdon: Routledge.

Dowding K and Lewis C (2014) Australia: Ministerial Characteristics in the Australian Federal Government. In Dowding K and Dumont P (eds), The Selection of Ministers Around the World. Abingdon: Routledge, pp. 44-60.

Elzinga CH (2006) Sequence Analysis: Metric Representations of Categorical Time Series: Sociological Methods and Research. Unpublished paper, http://home.fsw.vu.nl/ch.elzinga/MetricsRevision.pdf (accessed 23 September 2019).

Escobar-Lemmon M and Taylor-Robinson M (2005) Women Ministers in Latin American Government: When, Where, and Why? American Journal of Political Science 49(4), 829-844.

Escobar-Lemmon M and Taylor-Robinson M (2016) Women in Presidential Cabinets: Power Players or Abundant Tokens? Oxford: Oxford University Press.

Fasang AE (2012) Retirement Patterns and Income Inequality. Social Forces 90(3), 685-711.

Franks CE (1987) The Parliament of Canada. Toronto: University of Toronto Press.

Heard AD (1991) Canadian Constitutional Conventions: The Marriage of Law and Politics. Toronto: Oxford University Press.

Jäckle S (2014) Ministerial Positions on the Level of the German Länder - Stepping Stones or Dead Ends for Political Careers? Paper presented at the European Consortium for Political Research General Conference, Glasgow, 3 September.

Jäckle S (2016) Pathways to Karlsruhe: A Sequence Analysis of the Careers of German Federal Constitutional Court Judges. German Politics 25(1), 25-53.

Jäckle S and Kerby M (2018) Temporal Methods in Political Elite Studies. In Best H and Higley J (eds), The Palgrave Handbook of Political Elites. London: Palgrave Macmillan, pp. 115-133.

Kenig O and Barnea S (2014) Israel: The Choosing of the Chosen. In Dowding K and Dumont P (eds), The Selection of Ministers Around the World. Abingdon: Routledge, pp. 178-196.

Kerby M (2009) Worth the Wait: The Determinants of Ministerial Appointment in Canada, 1935-2008. Canadian Journal of Political Science 42(3), 593-612.

Kerby M (2011) Combining the Hazards of Ministerial Appointment AND Ministerial Exit in the Canadian Federal Cabinet. Canadian Journal of Political Science/Revue canadienne de science politique 44(3), 595-612.

Kerby M (2014) Canada: Ministerial Careers. In Dowding K and Dumont P (eds), The Selection of Ministers Around the World. Abingdon: Routledge, pp. 264-282.

Kerby M and Banfield AC (2013) A Sequence Analysis of Canadian Supreme Court Judicial Careers. Paper presented at the European Consortium for Political Research General Conference, Bordeaux, 4 September.

Kerby M and Blidook K (2011) It's Not You, It's Me: Determinants of Voluntary Legislative Turnover in Canada. Legislative Studies Quarterly 36(4), 621-643.

King A (1981) The Rise of the Career Politician in Britain - and its Consequences. British Journal of Political Science 11(3), 249-285.

Krook ML and O'Brien DZ (2012) All the President's Men? The Appointment of Female Cabinet Ministers Worldwide. Journal of Politics 74(3), 840-855.

Lesnard L (2014) Using Optimal Matching Analysis in Sociology: Cost Setting and Sociology of Time. In Blanchard P, Bühlmann F and Gauthier J-A (eds), Advances in Sequence Analysis: Theory, Method, Applications. Dordrecht: Springer, pp. 39-50. 
Manow P (2012) Wahlkreis-oder Listenabgeordneter, Typus oder Episode? Eine Sequenzanalyse der Wege in den Bundestag. Politische Vierteljahresschrift 53(1), 53-78.

Martin JM (1989) The Recruitment of Women to Cabinet and Subcabinet Posts. Western Political Quarterly 42(1), 161-172.

Matland RE and Studlar DT (2004) Determinants of Legislative Turnover: A Cross-National Analysis. British Journal of Political Science 34, 87-108.

Moncrief GF and Studlar DT (1996) Women Cabinet Ministers in Canadian Provinces 1976-1994. Canadian Parliamentary Review 19(3), 10-13.

Mufti M (2014) Pakistan: Ministerial Turnover in the Federal Cabinet. In Dowding K and Dumont P (eds), The Selection of Ministers Around the World. Abingdon: Routledge, pp. 117-138.

Müller WC and Strøm K (1999) Policy, Office, or Votes? How Political Parties in Western Europe Make Hard Decisions. Cambridge: Cambridge University Press.

Nikolenyi C (2014) India: The Selection and De-Selection of Cabinet Ministers. In Dowding K and Dumont P (eds), The Selection of Ministers Around the World. Abingdon: Routledge, pp. 99-116.

Real-Dato J and Alarcón-González FJ (2012) The Significance of the European Parliament in Political Careers: Evidence from the Careers of Spanish MEPs (1986-2010). Paper presented at Assessing the Effects of the Preferences and Trajectories of Political Elites, Dublin, 24 June.

Robette N and Bry X (2012) Harpoon or Bait? A Comparison of Various Metrics in Fishing for Sequence Patterns. Bulletin of Sociological Methodology/Bulletin de méthodologie sociologique 116(1), 5-24.

Savoie D (1999) Governing from the Centre: The Concentration of Power in Canadian Politics, 1st edn. Toronto: University of Toronto Press.

Searing D (1985) The Role of the Good Constituency Member and the Practice of Representation in Great Britain. Journal of Politics 47(2), 348-381.

Searing D (1987) New Roles for Postwar British Politics: Ideologues, Generalists, Specialists, and the Progress of Professionalization in Parliament. Comparative Politics 19(4), 431-452.

Searing D (1994) Westminster's World: Understanding Political Roles. Cambridge, MA: Harvard University Press.

Snagovsky F and Kerby M (2018) The Electoral Consequences of Party Switching in Canada: 1945-2011. Canadian Journal of Political Science/Revue canadienne de science politique 51, 425-445.

Statistics Canada (2017) Population by Year, by Province and Territory (Number). www.statcan.gc.ca/ tables-tableaux/sum-som/101/cst01/demo02a-eng.htm.

Studlar DT and Moncrief G (1997) The Recruitment of Women Cabinet Ministers in the Canadian Provinces. Governance: An International Journal of Policy and Administration 10, 67-81.

Studlar DT and Moncrief G (1999) Women's Work? The Distribution and Prestige of Portfolios in the Canadian Provinces. Governance: An International Journal of Policy and Administration 12(4), 379-395.

Taflaga M and Kerby M (2019) Who Does What Work in a Ministerial Office: Politically Appointed Staff and the Descriptive Representation of Women in Australian Political Offices: 1970-2010. Political Studies, published early online, June, https://doi.org/10.1177/0032321719853459

Tepe M and Marcinkiewicz K (2013) Career Paths of the German Administrative Elite: A Quantitative Sequence Analysis of Administrative State Secretaries' Biographies. Paper presented at the European Consortium for Political Research General Conference, Bordeaux, 4 September.

Tremblay M (2013) Women's Access to Cabinets in Canada: Assessing the Role of Some Institutional Variables. Canadian Political Science Review 6(2-3), 159-170.

Trimble L and Tremblay $\mathbf{M}$ (2005) Representation of Canadian Women at the Cabinet Table. Atlantis: Critical Studies in Gender, Culture and Social Justice 30(1), 31-45.

Zwinkels T and Mills M (2015) Pathways to Power: Careers, Communication Skills, Political Contacts and the Obtainment of Ministerial Office. Paper presented at Assessing the Effects of the Preferences and Trajectories of Political Elites, Montreal, 26 August.

Cite this article: Kerby M, Snagovsky F (2019). Not All Experience is Created Equal: MP Career Typologies and Ministerial Appointments in the Canadian House of Commons, 1968-2015. Government and Opposition: An International Journal of Comparative Politics 1-19. https://doi.org/10.1017/gov.2019.29 